\title{
Accessing the European funds for agriculture and rural development in Romania for the 2014-2020 period
}

\author{
Mihai DINU \\ Bucharest University of Economic Studies, Bucharest, Romania \\ mihai.dinu@eam.ase.ro \\ Simona Roxana PĂTĂRLĂGEANU \\ Bucharest University of Economic Studies, Bucharest, Romania \\ rpatarlageanu@eam.ase.ro \\ Bogdan CHIRIPUCI \\ Bucharest University of Economic Studies, Romania \\ bogdan.chiripuci@gmail.com \\ Marius CONSTANTIN \\ Bucharest University of Economic Studies, Bucharest, Romania \\ constantinmarius15@stud.ase.ro
}

\begin{abstract}
This paper aims at identifying the extent to which Romania has accessed European funds for agriculture and rural development in the 2014-2020 period. During this financing period, Romania has received more than 8.12 billion euros from the European Union budget, more precisely from the Agricultural Fund for Rural Development (EAFDR), through the National Rural Development Programme (NRDP). Five percent of the available amount was allocated to the Leader approach at local level and at least 30\% was allotted for environmental protection measures. This paper will analyze the number of projects which were submitted, selected and contracted and the payments made until 2019. Subsequently, an analysis will be carried out of the NRDP sub-measures in order to prove the usefulness and necessity of this type of structural programme. The rate of absorbtion of European funds will be closely correlated with indicators such as the evolution of the GDP / inhabitant, the population and the number of enterprises in rural areas, the employed population and the number of enterprises in agriculture, forestry and fisheries, the development of villages through the construction or modernization of roads, sewage infrastructure, water and gas. To conclude, the positive and negative aspects regarding the implementation of European funds will be listed, especially in the fields of agriculture and rural development in Romania.
\end{abstract}

Keywords: European funds, agriculture, rural development, Romania

\section{Introduction}

The National Rural Development Programme (NRDP) is a programme coordinated by the Ministry of Agriculture and Rural Development, which was approved after mediation with the European Commission. It is structured in measures, aiming at supporting the development of the rural areas in Romania.

When the NRDP 2014-2020 was elaborated, the initial analysis regarding labour productivity in the Romanian agriculture, forestry and fishing industry in 2012 indicated a value of $€ 2,464$ per employed person, which was almost five times lower than the national average, taking into account that the employed population was decreasing at both national and rural level (European Commission, 2016). Moreover, 40\% of the population in rural areas was at risk of 
poverty and social exclusion. At the beginning of the programming period, the quality of life in the rural areas was still affected by the infrastructure deficiencies.

The main objective of this research aims at identifying the extent to which Romania has accessed European funds for agriculture and rural development in the 2014-2020 period, correlating the rate of absorbtion of Agricultural Fund for Rural Development (EAFDR) with specific indicators that track improvements made in agriculture and in the rural Romania.

\section{Literature review}

The restauration of agricultural holdings and the increase of their viability represents one of the NRDP 2014-2020 objectives, along with others such as: ensuring the sustainability of the management of natural resources and climate action, diversifying the economic activities in rural areas, generating jobs, improving the infrastructure and services in order to increase the quality of life. Romania occupies the 6th place at European Union level in terms of the agricultural area used, which highlights the importance of the previously mentioned objectives in the case of the rural areas in Romania (Ioniţă, Mărcuţă and Mărcuţă, 2018).

The main development priorities for rural Romania included in the NRDP 2014-2020 were aiming towards the following aspects: knowledge transfer and innovation, increasing the viability and competitiveness of agriculture; preserving, restoring and enhancing ecosystems; encouraging the efficient use of resources in order to accelerate the transition to a low carbon economy. Lastly, the NRDP 2014-2020 promoted a priority regarding social inclusion in the rural areas, poverty reduction and sustainable economic development. Some authors consider that encouraging the development of local communities via the LEADER approach is also one of the main priorities in the rural areas of Romania (Kuciel, 2016), while others believe that landscaping and spatial planning are the appropriate tools that can ensure the durable development objective for these areas (Lucian, 2018). A key aspect for reaching the durable development objective in rural areas is represented by the active and responsible involvement of public institutions (both central and local), private sector (especially entrepreneurs), local community, professional associations, social partners (Dima et al., 2018).

Conserving the Romanian traditional village to rediscover resources and exploring its non-agricultural potential are some development directions that should be adapted to local needs in order to produce the desired effects of the NRDP 2014-2020 (Popescu, 2015). The LEADER approach meets most of these needs through micro-regional interventions, which focus on using the local resources and specificities. These interventions provide local actors with the opportunity to propose and eventually implement original solutions to the specific local problems existing in their communities.

Even though some studies suggest that the majority of payments that focus mainly on the competitiveness of the agricultural sector do not show either a negative or positive effect on improving the quality of life of the Romanian rural population (Mack, Fîntîneru and Kohler, 2018) and some authors demonstrated the lack of effectiveness of LAGs projects in promoting non-agricultural rural development (Pocol et al., 2017), further research is still needed in order to completely understand all the effects of the financing from the European Agricultural Fund for Rural Development (EAFRD) via NRDP.

Despite the fact that some EAFRD beneficiaries consider that it takes a long time between the submission of the funding proposal and its approval (Raicov et al., 2018), these funds 
certainly help when starting a new business, which contributes to ensuring rural economic growth (Rovinaru and Pop, 2013).

\section{Methodology}

The statistical methods involved in carrying out this research included planning, designing, collecting data and analysing data in order to ensure drawing meaningful interpretation and reporting of findings (Ali and Bhaskar, 2016). This statistical analysis provides meaning to the meaningless numbers and explains the extent to which Romania has accessed European funds for agriculture and rural development in the 2014-2020 period, correlating the rate of absorbtion of Agricultural Fund for Rural Development with specific indicators that track improvements made in agriculture and in the rural Romania.

The values of the previously mentioned indicators are available online on the official website of the National Institute of Statistics - Romania and data regarding the European funds for agriculture and rural development in the 2014-2020 period were taken over from the official website of the National Rural Development Programme Romania.

\section{Results and discussions}

By 19 December 2019, 37,218 financing contracts worth 4.54 billion Euro had been signed in Romania through the NRDP, representing a 48.16\% contracting rate of the allotted amounts for the 2014-2020 period. The volume of payments made amounted to 4.38 billion euro, which accounts for a consumption level of $46.45 \%$ in relation to the allocations for $2014-2020$. Thus, by 19 December 2019, less than 50\% of the number of projects concluded in the 2007-2013 programming period (i.e. 86,844) had been signed for the NRDP 2014-2020, while the allocated funds were almost the same.

The total public budget allocated in Romania to the NRDP 2014-2020 was 9.44 billion Euro for which 65,494 projects worth 9.49 billion Euro were submitted. Of these, 38,237 projects were selected and 37,218 contracts worth 4.54 billion Euro $(48.16 \%)$ were signed and payments of 4.38 billion Euro were made (46.45\%)

Table 1. Absorbtion of funds proposed through the NRDP 2014-2020 as of 19 December 2019

\begin{tabular}{|l|c|c|c|c|c|c|c|c|}
\hline Submeasure & $\begin{array}{c}\text { Public } \\
\text { contribution } \\
\text { (billion euro) }\end{array}$ & $\begin{array}{c}\text { Submitted } \\
\text { projects }\end{array}$ & $\begin{array}{c}\text { Selected } \\
\text { projects }\end{array}$ & $\begin{array}{c}\text { Contracted } \\
\text { projects }\end{array}$ & $\begin{array}{c}\text { Concluded } \\
\text { projects } \\
\text { (billion } \\
\text { euro) }\end{array}$ & $\begin{array}{c}\text { Contracting } \\
\text { rate (\%) }\end{array}$ & $\begin{array}{c}\text { Payments } \\
\text { made } \\
\text { (billion } \\
\text { euro) }\end{array}$ & $\begin{array}{c}\text { Payment } \\
\text { rate (\%) }\end{array}$ \\
\hline 11 & 54.19 & 478 & 257 & 257 & 5.74 & $10.59 \%$ & 3.77 & $6.96 \%$ \\
\hline 12 & 13.41 & 53 & 52 & 52 & 0.36 & $2.68 \%$ & 0.00 & $0.00 \%$ \\
\hline 21 & 11.11 & & & & 3.90 & $35.08 \%$ & 0.08 & $0.73 \%$ \\
\hline 31 & 6.11 & 0 & 0 & 0 & 0.00 & $0.00 \%$ & 0.00 & $0.00 \%$ \\
\hline 32 & 4.07 & 0 & 0 & 0 & 0.00 & $0.00 \%$ & 0.00 & $0.00 \%$ \\
\hline 41 & 877.67 & 4,181 & 1,938 & 1,938 & 890.16 & $101.42 \%$ & 468.01 & $53.32 \%$ \\
\hline $41 \mathrm{a}$ & 289.36 & 1,179 & 572 & 572 & 234.42 & $81.01 \%$ & 80.56 & $27.84 \%$ \\
\hline 42 & 495.48 & 1,047 & 658 & 658 & 306.47 & $61.85 \%$ & 111.65 & $22.53 \%$ \\
\hline $42 \mathrm{a}$ & 47.43 & 73.00 & 25 & 25 & 6.95 & $14.64 \%$ & 2.93 & $6.18 \%$ \\
\hline 43 & 675.25 & 1,090 & 554 & 554 & 391.61 & $58.00 \%$ & 185.31 & $27.44 \%$ \\
\hline
\end{tabular}




\begin{tabular}{|c|c|c|c|c|c|c|c|c|}
\hline 51 & 14.78 & 173 & 144 & 144 & 1.81 & $12.24 \%$ & 0.00 & $0.00 \%$ \\
\hline 52 & 13.68 & 0 & 0 & 0 & 0.00 & $0.00 \%$ & 0.00 & $0.00 \%$ \\
\hline 61 & 436.74 & 14,383 & 10,309 & 10,309 & 419.77 & $96.11 \%$ & 375.44 & $85.96 \%$ \\
\hline 62 & 111.57 & 6,331 & 1,967 & 1,967 & 113.80 & $102.00 \%$ & 86.52 & $77.55 \%$ \\
\hline 63 & 251.49 & 20,825 & 11,931 & 1,931 & 177.17 & $70.45 \%$ & 145.74 & $57.95 \%$ \\
\hline 64 & 176.50 & 2,600 & 1,040 & 1,040 & 152.53 & $86.42 \%$ & 73.80 & $41.81 \%$ \\
\hline 65 & 12.33 & 21 & 3 & 3 & 0.00 & $0.04 \%$ & 0.00 & $0.02 \%$ \\
\hline 72 & $1,109.06$ & 1,970 & 1,198 & 1,198 & $1,078.07$ & $97.21 \%$ & 605.22 & $54.57 \%$ \\
\hline 74 & 13.76 & 0 & 0 & 0 & 0.00 & $0.00 \%$ & 0.00 & $0.00 \%$ \\
\hline 76 & 197.01 & 939 & 688 & 688 & 211.29 & $107.25 \%$ & 109.94 & $55.80 \%$ \\
\hline 81 & 126.80 & 79 & 68 & 68 & 7.49 & $5.91 \%$ & 0.00 & $0.00 \%$ \\
\hline 91 & 14.74 & 44 & 10 & 10 & 3.37 & $22.87 \%$ & 1.91 & $12.98 \%$ \\
\hline $91 \mathrm{a}$ & 5.30 & 3 & 0 & 0 & 0.00 & $0.00 \%$ & 0.00 & $0.00 \%$ \\
\hline 10 & $1,069.00$ & & & & 0.00 & $0.00 \%$ & 365.02 & $34.15 \%$ \\
\hline 11 & 235.72 & & & & 0.00 & $0.00 \%$ & 134.95 & $57.25 \%$ \\
\hline 13 & $1,317.64$ & & & & 0.00 & $0.00 \%$ & $1,173.63$ & $89.07 \%$ \\
\hline 14 & 776.41 & & & & 0.00 & $0.00 \%$ & 91.09 & $11.73 \%$ \\
\hline 15.1 & 70.15 & 328 & 305 & 305 & 0.00 & $0.00 \%$ & 0.00 & $0.00 \%$ \\
\hline 16.1 & 6.72 & 136 & 24 & 24 & 0.00 & $0.00 \%$ & 0.00 & $0.00 \%$ \\
\hline $16.1 \mathrm{a}$ & 5.82 & 84 & 17 & 17 & 0.00 & $0.00 \%$ & 0.00 & $0.00 \%$ \\
\hline 16.4 & 10.09 & 266 & 60 & 60 & 4.60 & $45.65 \%$ & 1.55 & $15.38 \%$ \\
\hline $16.4 \mathrm{a}$ & 8.73 & 79 & 22 & 22 & 1.98 & $22.73 \%$ & 0.59 & $6.80 \%$ \\
\hline 17.1 & 42.80 & 1,578 & & & 0.89 & $2.09 \%$ & 0.47 & $1.10 \%$ \\
\hline 19.1 & 1.99 & 180 & 175 & 175 & 2.22 & $111.78 \%$ & 1.98 & $99.24 \%$ \\
\hline 19.2 & 495.60 & 7,338 & 6,206 & 6,206 & 352.14 & $71.05 \%$ & 168.61 & $34.02 \%$ \\
\hline 19.3 & 16.99 & 66 & 55 & 55 & 0.17 & $1.01 \%$ & 0.09 & $0.56 \%$ \\
\hline 19.4 & 123.01 & & & & 70.25 & $57.11 \%$ & 60.77 & $49.40 \%$ \\
\hline 20 & 209.10 & & & & 16.21 & $7.75 \%$ & 89.27 & $42.69 \%$ \\
\hline $\begin{array}{l}\text { Financial } \\
\text { instruments }\end{array}$ & 93.97 & & & & 93.88 & $99.90 \%$ & 46.94 & $49.95 \%$ \\
\hline TOTAL & $9,441.58$ & 65,494 & 38,237 & 38,237 & $4,547.25$ & $48.16 \%$ & $4,385.85$ & $46.45 \%$ \\
\hline
\end{tabular}

PICBE $\mid 720$

Source: Data processed from the madr.ro website https://www.madr.ro/pndr-2014-2020/implementare-pndr-20142020/situatia-proiectelor-depuse-2014-2020.html

The analysis of the data presented in Table 1 leads to the following general conclusions: - most projects were submitted for submeasures 6.3 Business start-up aid for the development of small farms (20,825 projects), 6.1 Aid for the settling in of young farmers (13,383 projects) and 19.2 Aid for the implementation of the measures within the local development strategy (7,338 projects);

- the most contracted projects were for submeasures 7.2 Renovation and development of villages (1.08 billion euro), 4.1 Investments in agricultural exploitations ( 0.89 billion euro) and 6.1 Aid for the settling in of young farmers ( 0.41 billion euro); 
- the fewest projects were submitted for submeasure 9.1a Setting up groups of producers in the fruit growing sector (9 projects).

The absorbtion rate of the funds allocated through the NRDP until December 2019 can be considered acceptable if we take into account the fact that there is still time for Romania to contract new projects and to make payments.

PICBE | 721

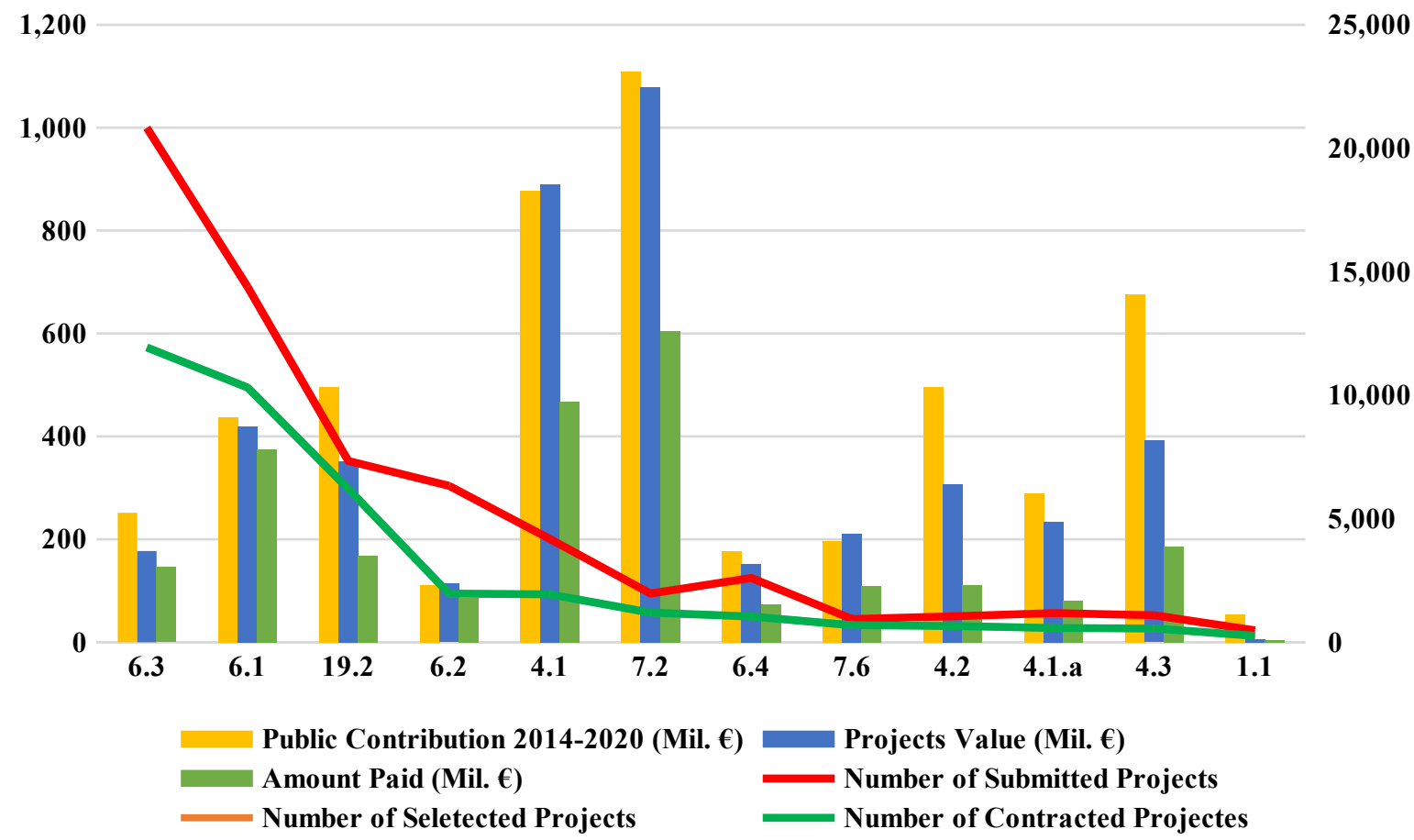

Figure 1. Top of the best performing submeasures, based on the number of contracted projects Source: Own conceptualization based on available data

According to Figure 1, submeasure 6.3 Business start-up aid for the development of small farms was the one that had the most projects submitted for funding (20,825 projects). Unfortunately, only $57,29 \%$ of the total submitted projects were actually selected and contracted, with a total value of 251 million euros (117 paid so far, which represents 46,61\%). The support granted via this submeasure for small farms is a tool designed to determine mainly the structural transformation and opening to market of the small farms. Moreover, the implementation of this submeasure is meant to increase of small farms' capacity to identify new opportunities for the capitalisation of their production. The support was granted as a flat-rate for the implementation of the objectives justified by the beneficiaries in the business plan.

Submeasure 19.2 Preparatory support consists in the aid provided to local private-public partnerships for the development of the local development strategy. This submeasure is the one that had the highest contracting rate within the NRDP 2014-2020, taking into account the big number of the total projects submitted $(7,338$ projects with a contracting rate of $84,57 \%)$. The total value of the projects was 352 million euros and the amount paid as of December 2019 was 168 million euros $(47,72 \%)$. Another main objective of this submeasure aims at enhancing the collaboration capacity required to develop integrated strategies. This is believed to give the 
possibility to rural stakeholders and/or to representatives of different fields of activity to work together and interact for the benefit of communities in the LEADER territories.

On the other hand, submeasures such as 4.1 Investments in agricultural holdings (support investments aiming at increasing the competitiveness of agricultural holdings and improving the quality of fixed assets) and 7.2 Investments in the creation and upgrade of small-scale infrastructure (which was previously explained) have a considerable amount of projects submitted for funding $(4.1-1,938$ contracted projects and $7.2-1,198$ contracted projects), but the value of these projects is much higher compared to others within the NRPD 2014-2020 (877 million euros for submeasure 4.1 and 1,078 million euros for submeasure 7.2).
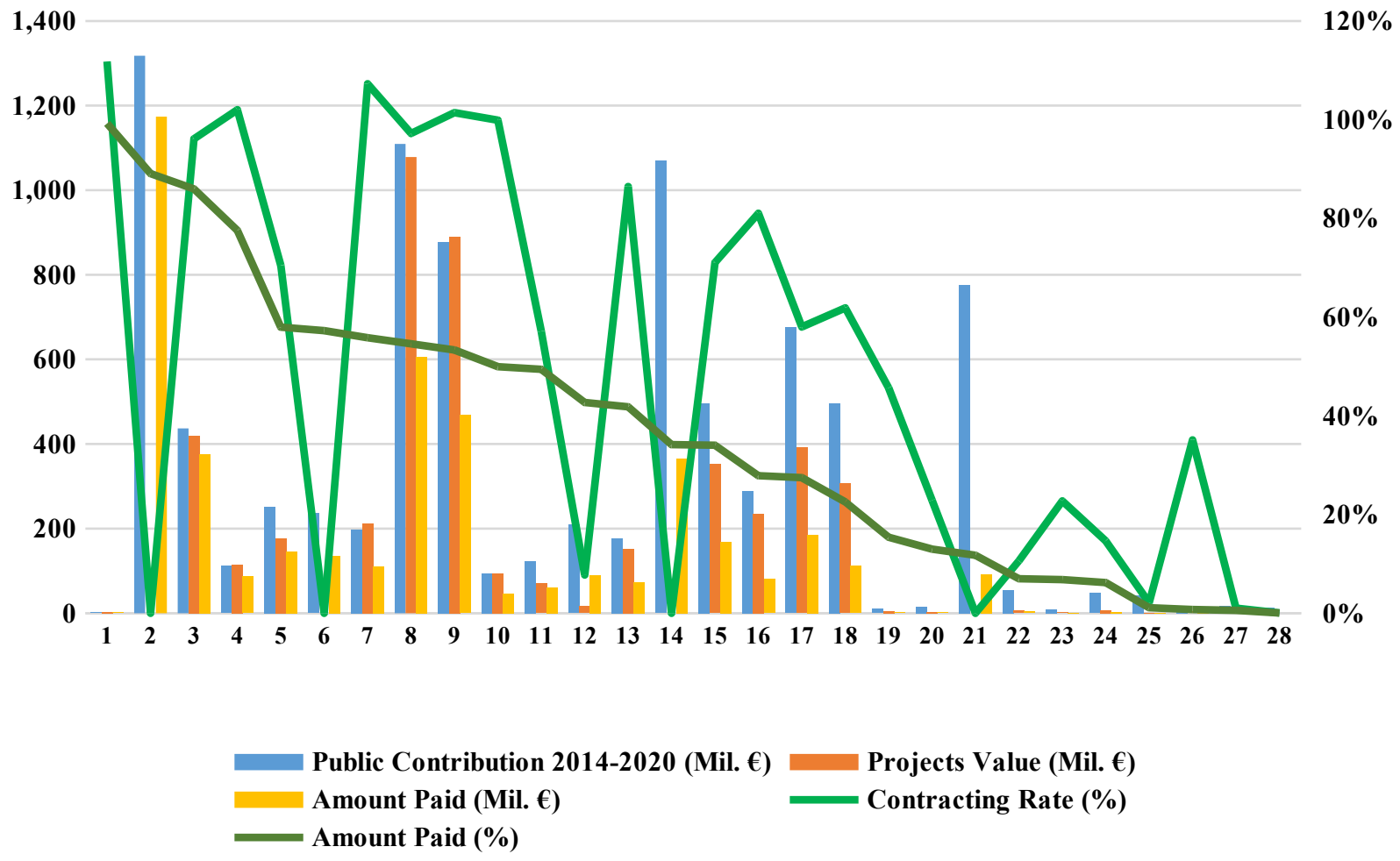

Figure 2. Top performing submeasures, based on the amount paid (\%) to the beneficiaries Source: Own conceptualization based on available data

According to Figure 2, submeasure 19.3 Preparation and implementation of Local Action Group cooperation activities has the highest amount paid to beneficiaries expressed in percentages $(99,24 \%)$ among all the others submeasures, but the total amount paid is of only 1,98 million euros. However, the second submeasure in the top of the best performing submeasures based on the amount paid (\%) to the beneficiaries is submeasure 1.3 Payments to areas facing natural or other specific constraints $(89,07 \%)$ with a total value of 1.173 million euros. This submeasure has the highest amount paid of all the submeasures and this is because in terms of agricultural productivity, Romania presents wide areas with natural limitations caused by unfavourable climate and biophysical conditions. Some examples of such areas are the Carpathian Mountains and the Danube Delta. The support provided via this submeasure is intended to compensate for the disadvantages faced by the farmers who carry out agricultural 
activities and to decrease the risk of agricultural abandonment (unfortunately higher in such areas).

Additionally, submeasure 7.2 Investments in the creation and upgrade of small-scale infrastructure is one the performant submeasures in terms of the amount paid to the beneficiaries $(54,57 \%)$ out of the projects' total value, especially since 605 million euros were already paid, as of December 2019. This submeasure has the second highest amount paid to beneficiaries of all the other NRPD 2014-2020 submeasures. It supports investments for the improvement of small scale basic infrastructure, in order to ensure a sustainable economic development, along with the reduction of poverty in rural areas. Investments in the creation and upgrade of small-scale infrastructure involves the financing (creation, expansion and improvement) of a local-interest road networks, public water supply network, public wastewater network, kindergartens and nurseries, after-school units, medical and social services (rural medical clinics and community care centres). Therefore, among others, the importance of this submeasure for the rural areas in Romania is also expressed by the need of the rural communities to improve the infrastructure locally, reflected in the total number of submitted projects $(1,970$ projects submitted, 1,198 contracted) and in the total amount of the non-refundable contribution granted to the beneficiaries.

Table 2. KPIs dynamics based on the implementation of the NRDP 2014-2020

\begin{tabular}{|l|c|c|c|}
\hline \multirow{2}{*}{ KPI } & \multicolumn{2}{|c|}{ YEARS } & $\begin{array}{c}\text { Percentage } \\
\text { Change } \\
\text { (2018 vs 2014) }\end{array}$ \\
\cline { 2 - 4 } & $\mathbf{2 0 1 4}$ & $\mathbf{2 0 1 8}$ & $44.45 \%$ \\
\hline NOMINAL GROSS DOMESTIC PRODUCT & $33,569 \mathrm{RON}$ & $48,491 \mathrm{RON}$ & $-1.88 \%$ \\
\hline RURAL RESIDENT POPULATION & $9,200,472$ & $9,027,161$ & \\
\hline $\begin{array}{l}\text { RURAL RESIDENT POPULATION IN } \\
\text { RELATION TO THE TOTAL RESIDENT } \\
\text { POPULATION }\end{array}$ & $46.11 \%$ & $46.22 \%$ & $0.24 \%$ \\
\hline $\begin{array}{l}\text { ECONOMICALLY ACTIVE POPULATION IN } \\
\text { AGRICULTURE, FORESTRY AND FISHING }\end{array}$ & $2,304,100$ & $1,759,500$ & $-23.64 \%$ \\
\hline $\begin{array}{l}\text { ECONOMICALLY ACTIVE POPULATION IN } \\
\text { AGRICULTURE, FORESTRY AND FISHING, IN } \\
\text { RELATION TO THE TOTAL ACTIVE } \\
\text { POPULATION }\end{array}$ & $27.33 \%$ & $20.93 \%$ & $-23.42 \%$ \\
\hline $\begin{array}{l}\text { ACTIVE ENTERPRISES IN AGRICULTURE, } \\
\text { FORESTRY AND FISHING }\end{array}$ & 17,471 & 20,514 & $17.42 \%$ \\
\hline $\begin{array}{l}\text { ACTIVE ENTERPRISES IN AGRICULTURE, } \\
\text { FORESTRY AND FISHING IN RELATION TO } \\
\text { THE TOTAL ACTIVE ENTERPRISES }\end{array}$ & $3.44 \%$ & $3.56 \%$ & $3.34 \%$ \\
\hline $\begin{array}{l}\text { LENGTH OF THE PUBLIC COMMUNAL } \\
\text { ROADS }\end{array}$ & $\begin{array}{c}32,407 \\
\text { kilometers }\end{array}$ & $\begin{array}{c}33,409 \\
\text { kilometers }\end{array}$ & $3.09 \%$ \\
\hline $\begin{array}{l}\text { LENGTH OF THE MODERNISED PUBLIC } \\
\text { COMMUNAL ROADS }\end{array}$ & $\begin{array}{c}3,152 \\
\text { kilometers }\end{array}$ & $\begin{array}{c}5,682 \\
\text { kilometers }\end{array}$ & $80.27 \%$ \\
\hline
\end{tabular}




\begin{tabular}{|c|c|c|c|}
\hline $\begin{array}{l}\text { LENGTH OF THE MODERNISED PUBLIC } \\
\text { COMMUNAL ROADS IN RELATION TO THE } \\
\text { LENGTH OF PUBLIC COMMUNAL ROADS }\end{array}$ & $9.73 \%$ & $17.01 \%$ & $74.86 \%$ \\
\hline $\begin{array}{l}\text { NUMBER OF RURAL LOCALITIES WHERE } \\
\text { NATURAL GAS IS DISTRIBUTED }\end{array}$ & 661 & 697 & $5.45 \%$ \\
\hline $\begin{array}{l}\text { NUMBER OF THE RURAL LOCALITIES } \\
\text { WHERE NATURAL GAS IS DISTRIBUTED IN } \\
\text { RELATION TO ALL THE LOCALITIES WHERE } \\
\text { GAS IS DISTRIBUTED }\end{array}$ & $72.96 \%$ & $73.76 \%$ & $1.09 \%$ \\
\hline $\begin{array}{l}\text { NUMBER OF RURAL LOCALITIES } \\
\text { PUITH } \\
\text { PUBIC SEWERAGE INSTALLATIONS }\end{array}$ & 760 & 990 & $30.26 \%$ \\
\hline $\begin{array}{l}\text { NUMBER OF THE RURAL LOCALITIES WITH } \\
\text { PUBLIC SEWERAGE INSTALLATIONS IN } \\
\text { RELATION TO ALL THE LOCALITIES WITH } \\
\text { PUBLIC SEWERAGE INSTALLATIONS }\end{array}$ & $70.96 \%$ & $75.86 \%$ & $6.91 \%$ \\
\hline
\end{tabular}

PICBE | 724

Source: Own conceptualization based on the National Institute of Statistics - Romania data

Data concerning relevant KPI dynamics based on the implementation of the NRDP 2014-2020 in Romania were collected from the National Institute of Statistics in January 2020 and centralised in Table 2 . The values of the key performance indicators were analysed taking into account the fact that 2014 was the first year when the beneficiaries of the NRDP 2014-2020 started to access the European Agricultural Fund for Rural Development. Unfortunately, official KPI data is not available from 2018 until 2020. Therefore, in order to quantify the impact of the NRDP

2014-2020 more accurately, it is recommended to compare the values recorded in 2020 (when they become available) to the already available ones for 2014. Another limitation of this research is that the data included in Table 2 refers to the national KPI values, whereas the effects of the NRDP 2014-2020 are better observed when analysing its impact locally.

Figure 3. KPI dynamics (2018 in relation to 2014)

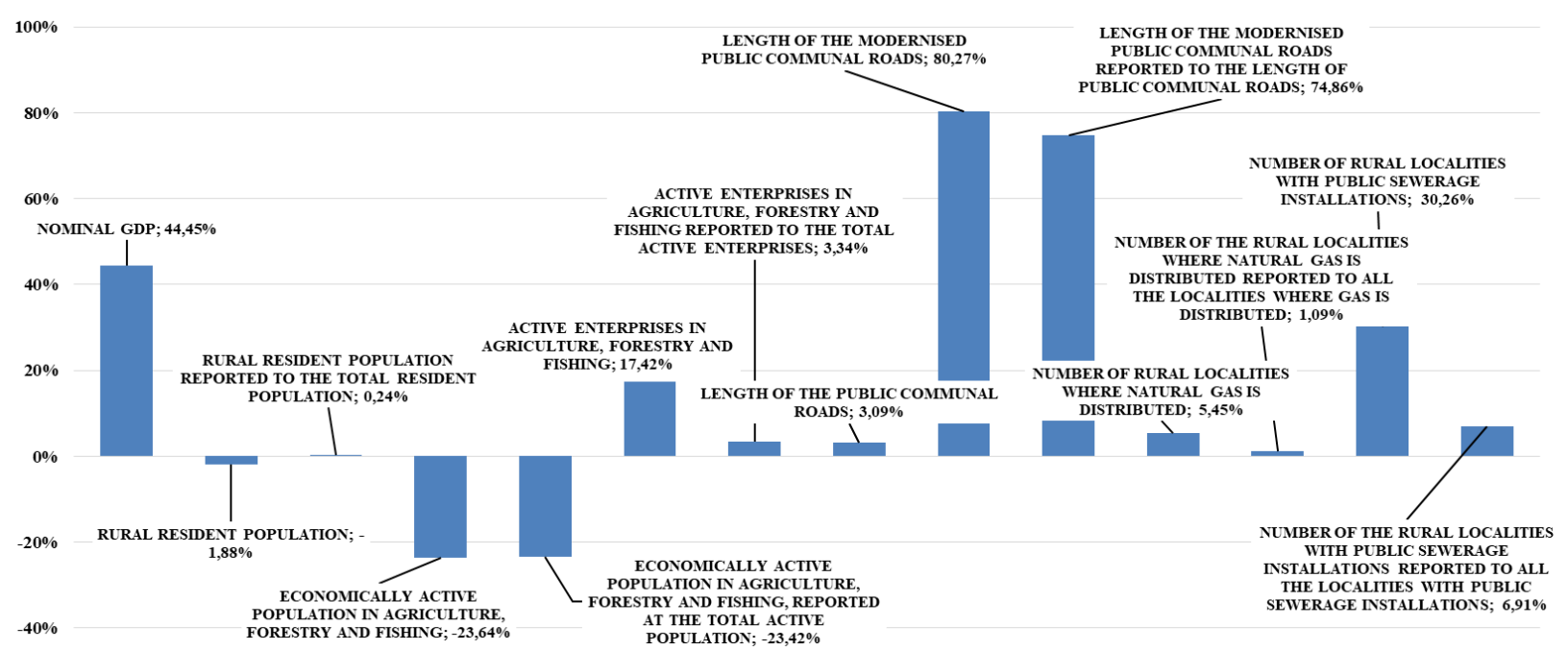

Source: Own conceptualization based on the National Institute of Statistics - Romania data 
The data presented in Figure 3, which covers the situation ever since the implementation phase of the NRDP 2014-2020 started in Romania at the beginning of 2014, bring forward the following facts:

The nominal gross domestic product increased by 14,922 RON (44.45\%) in 2018, as compared to its value in 2014 (33,569 RON). However, during the same period of time, the resident rural population decreased by $1.88 \%$ (173,311 people), even though this population category saw an increase by 0.24 percentage points in relation to the total resident population (from $46.11 \%$ in 2014 to $46.22 \%$ in 2018 );

When analysing the KPIs illustrated in Figure 3 one can notice that the biggest decrease over time was experienced by the economically active population in agriculture, forestry and fishing. The decrease is of $23.64 \%$ (2018 in relation to 2014), which represents a deficit of 544,600 economically active people in agriculture, forestry and fishing. This triggered another decrease by $23.42 \%$ of the economically active population in agriculture, forestry and fishing, in comparison to the total economically active population (2018 in relation to 2014). Based on the previously mentioned KPIs, the measures included in the NRDP 2014-2020 did not manage to attract and retain the economically active population in agriculture, forestry and fishing, as the results reflected in the KPI indicate;

On the other hand, the number of active enterprises in agriculture, forestry and fishing increased from 17,471 in 2014 to 20,514 (17.42\% up) in 2018, which had a positive effect on the percentage of the active enterprises in agriculture, forestry and fishing in the total active enterprises (nationally), because it went up by 3.34 percentage points. Because of the dynamics of the previously mentioned indicators, the effects of the NRDP are visible before the year 2020 which marks the end of the programming period;

The biggest increase in 2018 in relation to 2014 is flagged by a very important KPI for the rural areas of Romania: the length of the modernised public communal roads, which increased by 2,530 kilometers (from 3,152 in 2014 to 5,682 in 2018, representing an $80.27 \%$ increase). Moreover, the length of the public communal roads grew by 1,002 kilometers (a $3.09 \%$ increase) in 2018 as compared to 2014;

The number of rural localities where natural gas is distributed also went up from 661 in 2014 to $697(5,45 \%)$ in 2018 - which is underwhelming if we compare it to the $30.26 \%$ increase in the number of rural localities with public sewerage installations (from 760 to 990). However, in both cases, the implementation of the measures and submeasures within the NRDP have contributed to improving the quality of life in the rural areas of Romania.

\section{Conclusion}

The National Rural Development Programme 2014-2020 is one of the key vectors that pushes the rural areas of Romania towards a more sustainable future. It provides support for the restauration of agricultural holdings and aims to increase their viability. The NRDP ensures the sustainability of the management of natural resources and climate action and the diversification of the economic activities in rural areas, it generates jobs and improves the infrastructure and services.

Preparation and implementation of Local Action Group cooperation activities was the NRDP submeasure with the lowest amount paid to beneficiaries (expressed in percentages, 99.24\%) of all the other submeasures, but the total amount paid is only 1.98 million euros. Payments to areas facing natural or other specific constraints was the submeasure with the 
highest amount paid to beneficiaries (1,173 million), whereas Business start-up aid for development of small farms was the submeasure that had the most projects submitted for funding (20,825 projects, with a $57.29 \%$ contracting rate).

It was demonstrated in this paper that the implementation of the measures and submeasures included in the NRDP 2014-2020 has had a positive impact on almost all the analysed KPIs, with the exception of the economically active population in agriculture, forestry and fishing, which decreased in 2018 by 544,600 people $(-23,64 \%)$, in relation to 2014 . It is expected that the effects of the implementation of the NRDP measures and submeasures will be reflected more accurately in the KPIs values recorded in 2020.

One of the limitations of this study is that the research was carried out from a macro perspective, (nationally) and not locally. Further research should consider a local approach of the stage of the NRDP implementation progress, as well as of the KPI values which will be recorded closer to the end of the programming period.

\section{References}

Ali, Z., \& Bhaskar, Sb. (2016). Basic statistical tools in research and data analysis. Indian Journal of Anaesthesia, 60(9), 662. https://doi.org/10.4103/0019-5049.190623

Dima, A.M., Begu, L., Vasilescu, M.D., \& Maassen, M.A. (2018). The relationship between the knowledge conomy and global competitiveness in the European Union. Sustainability, 10, 1706.

Ioniţă, N., Mărcuţă, L., \& Mărcuţă, A. G. (2018). The Evolution of Agricultural Holdings in Macro-Region Four (South-West Oltenia) after Romania's Integration into the European Union. Scientific Papers Series Management, Economic Engineering in Agriculture and Rural Development, 18(2), 255-258.

Kuciel, E. G. (2016). The Financing of the Romanian Rural Development Projects through the EU Funds. Competitiveness of Agro-Food and Environmental Economy.

Lucian, P. (2018). Durable Rural Development Through the 2014 - 2020 National Rural Development Program. Studies in Business and Economics, 13(2), 147-152.

Mack, G., Fîntîneru, G., \& Kohler, A. (2018). Do Rural Development Measures Improve Vitality of Rural Areas in Romania? AgroLife Scientific Journal, 7(2).

Ministry of Agriculture and Rural Development. (2019). National Rural Development Programme (PNDR) 2014-2020

Ministry of Agriculture and Rural Development. (2019). National Rural Development Programme (PNDR) 2014-2020. Results and perspectives.

Ministry of Agriculture and Rural Development. (2019). https://www.madr.ro/pndr-20142020/implementare-pndr-2014-2020/situatia-proiectelor-depuse-2014-2020.html

Pocol, C. B., Moldovan-Teselios, C., Cavicchioli, D., \& Cordea, M. I. (2017). Has the Leader Programme Been Effective in Promoting Local Rural Development? An Evaluation on Two Romanian Regions. AgroLife Scientific Journal, 6(1), 201-211.

Popescu, C. (2015). Association and Cooperation in Romanian Rural Areas - The Leader Experience. Journal of Community Positive Practices, XV(2), 28-42.

Raicov, M., Rujescu, C., Feher, A., \& Merce, I. (2018). The determination and ranking of factors bearing an influence over the ability to absorb rural development funds in Timis County, Romania. AIP Conference Proceedings. 
Rovinaru, M., \& Pop, L. (2013). Developing Rural Tourism through European Funds. Studies in Business and Economics, 8(3), 164-174.

Vladu, M., Pânzaru, R. L., \& Vladu, C.-E. (2019). Studies on the current stage of the investments made, for the development of storage capacities of field crops production, through the sub-measure 4.2 of the "National Program for Rural Development 2014-2020", in the South-West Region Oltenia. Romanian Agricultural Research, 2019(36), 241-250.

PICBE $\mid 727$

DOI: 10.2478/picbe-2020-0068, pp. 717-727, ISSN 2558-9652| Proceedings of the $14^{\text {th }}$ International Conference on Business Excellence 2020 